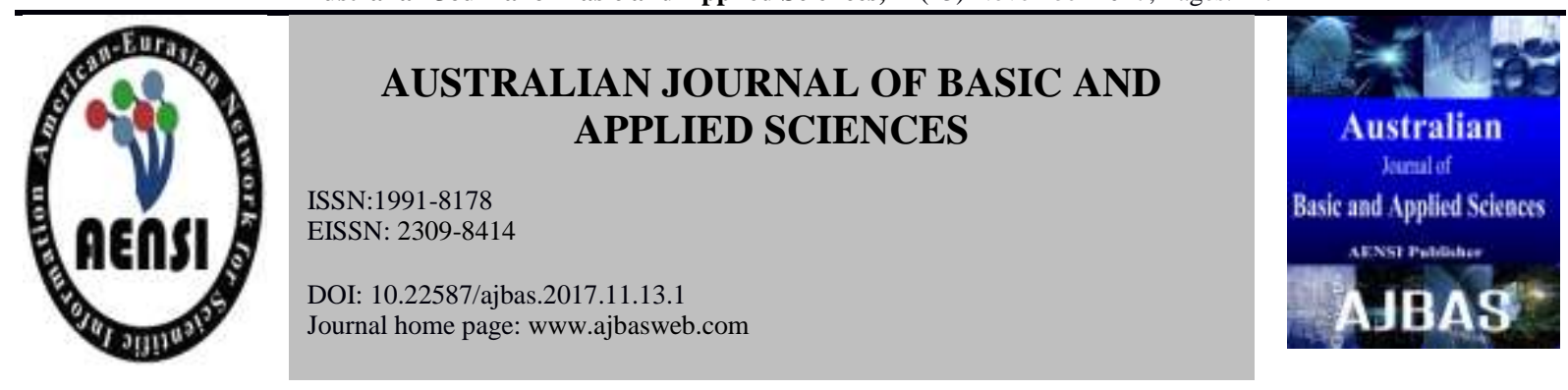

\title{
Artificial Neural Networks For Predicting Soil Organic Carbon Stocks
}

${ }^{1}$ William Macedo Delarmelina, ${ }^{1}$ Julia Siqueira Moreau, ${ }^{2}$ Marcos Vinicius Winckler Caldeira, ${ }^{3}$ Daniel Henrique Breda Binoti, ${ }^{1}$ Diêgo Gomes Júnior

${ }^{I}$ William Macedo Delarmelina, Forest Engineering, Professor at the Federal Institute of Espirito Santo, Phd student in Forest Science, Federal Universityof Espírito Santo, Jerônimo Monteiro, Espírito Santo, Brazil.

${ }^{I}$ Julia Siqueira Moreau, Forest Engineering, Phd Student in Forest Science, Federal Universityof Espírito Santo, Jerônimo Monteiro, Espírito Santo, Brazil.

${ }^{2}$ Marcos Vinicius Winckler Caldeira, Forest Engineering, Doctor in Forest Science, Professor of Federal University of Espírito Santo, Jerônimo Monteiro, Espírito Santo, Brazil.

${ }^{3}$ Daniel Henrique Breda Binoti, Forest Engineering, Post-doc in Federal University of Espírito Santo, Jerônimo Monteiro, Espírito Santo, Brazil.

${ }^{l}$ Diêgo Gomes Júnior, Doctor in Forest Science, Federal University of Espírito Santo, Jerônimo Monteiro, Espírito Santo, Brazil.

Address For Correspondence:

William Macedo Delarmelina, Federal Universityof Espírito Santo, Departmentof Forestry Sciences, CEP:29550-000, Jerônimo Monteiro, Espírito Santo, Brazil.

Email: williamdm@hotmail.com

\section{ARTICLE INFO}

\section{Article history:}

Received 19 August 2017

Accepted 1 November 2017

Available online 11 November 2017

Keywords:

Multilayer Perceptron, Tropical soils, Atlantic Forest.

\begin{abstract}
A B S T R A C T
Background: The use of mathematical models to estimate soil properties can be an alternative to reduce costs with data collection and analysis, allowing better quantification and characterization of soil attributes, highlighting in that branch artificial neural networks (ANN). Objective: This study aimed to propose, construct and validate a model to estimate soil organic carbon stock in a fragment of a semideciduous submontane forest through Artificial Neural Networks (ANN). Results: The best ANNwere selected based on the Pearson correlation coefficient (r), square root of the mean error (RMSE) and graphical analysis of residuals dispersion. The best correlation, both in training and validation, were observed for ANN1, which comprises the physicochemical variables of the soil, and for ANN 2, with chemical variables. The results of the use of neural network system to predict soil organic carbon stock are favorable. The input variables for the neural network used in this study are relatively easy to obtain, providing the use of the proposed methodology for the estimation of the stock of soil organic carbon. Conclusion: The physical and chemical properties of the soil used in this study allowed the prediction of organic carbon stock in semi-deciduous submontaneforest. ANN 2 was considered the most appropriate network to estimate the stock of organic carbon in the soil. However, further work should be carried out with different configurations of neural networks, i.e. using different architectures to obtain better correlation between the data of SOC stock and the physical and chemical soil properties, thus obtaining minor error in the response variable estimates.
\end{abstract}

\section{INTRODUCTION}

Brazil is a country rich in biodiversity due to the different biomes belonging to it (Silva et al. 2016; Ziembowicz et al., 2017). Than, the soil properties should be studied in order to generate knowledge about the structure, degree of conservation, fertility, among other factors that help in creating more efficient management practices and use of tropical soils, reducing impacts such as erosion and low productivity, being necessary to understand the dynamics of this forest in order to establish management plans for biodiversity and soil conservation (Curto et al., 2015; Arruda et al., 2013).

The organic matter (OM) is one of those attributes that have great influence on the behavior of soils, constituting the largest carbon reservoir in this compartment and makes decrease the fertilizers consume (Ribeiro et al., 2017; Marouni et al., 2016). The stock of soil organic carbon (SOC) can be changed with greater or lesser intensity, being one of the most sensitive attributes to the changes triggered by the management.

\section{Open Access Journal \\ Published BY AENSI Publication}

(C) 2017 AENSI Publisher All rights reserved

This work is licensed under the Creative Commons Attribution International License (CC BY).

http://creativecommons.org/licenses/by/4.0/

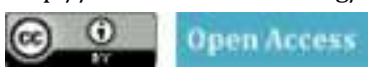

To Cite This Article: William Macedo Delarmelina, Julia Siqueira Moreau, Marcos Vinicius Winckler Caldeira, Daniel Henrique Breda Binoti, Diêgo Gomes Júnior., Artificial Neural Networks For Predicting Soil Organic Carbon Stocks. Aust. J. Basic \& Appl. Sci., 11(13): $1-7,2017$ 
Inadequate management practices can lead to the decline of the SOC stock, contributing to the increase of carbon dioxide (CO2) emissions to the atmosphere (Freixo et al., 2002).

In this context, the soil works as an alternative for the sequestration of carbon present in the atmosphere, which is an option to mitigate the increased concentrations of greenhouse gases, thus contributing to the reduction of global warming. (Rosa et al., 2014). Therefore, the assessment of the SOC stock in natural environments is of great importance due to their sensitivity to changes in soil quality, as it can provide support for establishing management systems and for maintaining sustainable ecosystems (Carneiro et al., 2009).

Chemical analysis carried out in the laboratory is the main method used to provide information about fertility and SOC, however, such method is considered expensive and time-consuming, given the amount of material needed and of data collection in the field that must be performed (Sousa Junior et al., 2011). Computational intelligence methods can be an alternative to reduce costs with data collection and analysis, allowing better quantification and characterization of soil attributes, highlighting in that branch artificial neural networks (ANN).

ANN is a mathematical model with artificial neurons connected to each other through connections associated with weights. A process called training, by which ANN learns and extracts the information describing the phenomenon under study, does the adjustment of weights. After training, the ANNis evaluated for its generalization capability, i.e., the ability to generate accurate estimates for unknowndata (Braga et al., 2007, Silva et al., 2010).

Researchers have shown that the ANN could be used to predict variables. In Brazil, Silveira et al. (2013) demonstrate that the use of ANN has potential in classifying preliminary soil mapping units using geomorphometry techniques. Bucene et al. (2004) showed that ANN was a very promising tool in soil differentiation for irrigation.

Therefore, to evaluate if the methodology created to obtain accurate estimates of carbon storage in the soil is technically applicable, reducing the chemical analysis costs, this study aimed to propose, construct and validate a model to estimate the stock of soil carbon in a semi-deciduous submontaneforest using artificial neural networks.

\section{MATERIAL AND METHODS}

\section{Data:}

Database for ANN training was obtained from soil analysis carried out in a fragment of semi-deciduous submontane forest. The forest fragment belongs to Cafundó Private Reserve of Natural Heritage (RPPN, in portuguese), located on the farm "Boa Esperança" in Cachoeiro de Itapemirim, Espírito Santo.

The climate of the studied region is Aw, with rainy summer and dry winter, the average temperature is 22.2 ${ }^{\circ} \mathrm{C}$ and the average annual precipitation is $1162 \mathrm{~mm}$ (Alvares et al., 2013). The terrain of RPPN Cafundóis characterized by having large flat areas with mild elevations and rocky outcrops at different points (IBGE, 1987). And has three different types of soil: Planosol, Cambisol and Latosol (Santos et al., 2013).

The data used were collected in April 2014 at four different depths $(0-5,5-10,10-20,20-40 \mathrm{~cm})$ in the same day and in 12 plots with dimensions equal to $20 \times 50 \mathrm{~m}$, totaling 48 samples per class soil. To compose these samples, five sub-samples were collected, randomly, in each plot, distant 300 meters from each other, which after homogenates resulted in three samples composed of plot, to obtain representativity.

Subsequently, the samples were sent for analysis in the soil laboratory of the Department of Soils of the Federal University of Viçosa (UFV), where analyzes chemical parameters were carried out following a methodology proposed by EMBRAPA (1997).

\section{Training and evaluation of $A N N$ :}

The variables used to estimate the stock of SOC were classified into quantitative: $\mathrm{pH}$, phosphorus, potassium, calcium, magnesium, effective CEC, bulk density, sand, silt and clay; and qualitative: soil class and sampling depth.

The trained networks are Multilayer Perceptron type, consisting of two layers of artificial neurons that process the data (intermediate layer and output layer) and a layer of artificial neurons that only receives the data (input layer) and directs them to the intermediate layer (Silva et al., 2010). The data were divided into the different stages: $70 \%$ used for training and 30\% for generalization (validation), and processed through software NeuroForest 3.3 (Binoti et al., 2014). The training algorithm used was Resilient Backpropagation, which, according to Leal et al. (2015), it is the most skilled and recommended choice for Multilayer Perceptron ANN type.

The architectures used and the input variables (Table 1) were tested in order to get the most viable alternative to predict the carbon stock. Accordingly, for the hidden layer, 5, 8, 10 and 13 neurons were tested. The total number of cycles equal to 3,000 or average square error of less than $1 \%$ was used asstopping criterion of the training algorithm, as suggested by Chen et al. (2014). 
Table 1: Composition of artificial neural networks chosen to estimate the stock of soil carbon in a fragment of semi-deciduous submontane forest, in the state of Espírito Santo.

\begin{tabular}{|c|c|c|c|c|}
\hline \multirow{2}{*}{ ANN } & \multirow{2}{*}{ Architeture } & \multicolumn{2}{|l|}{ Input Variables } & \multirow{2}{*}{ Output variable } \\
\hline & & Quantitative & Qualitative & \\
\hline 1 & $18-10-1$ & $\begin{array}{l}\text { pH; ECEC; P; K; Ca; Mg; BD; Sand; Silt; } \\
\text { Clay }\end{array}$ & S; Depth & Carbon Stock \\
\hline 2 & $14-13-1$ & $\mathrm{pH} ; \mathrm{ECEC} ; \mathrm{P} ; \mathrm{K} ; \mathrm{Ca} ; \mathrm{Mg}$ & S; Depth & Carbon Stock \\
\hline 3 & $7-13-1$ & pH; ECEC; P; K; Ca; Mg & - & Carbon Stock \\
\hline 4 & $12-10-1$ & BD; Sand; Silt; Clay & S; Depth & Carbon Stock \\
\hline 5 & $5-13-1$ & BD; Sand; Silt; Clay & - & Carbon Stock \\
\hline 6 & $9-10-1$ & $\mathrm{pH}$ & S; Depth & Carbon Stock \\
\hline 7 & $9-5-1$ & $\mathrm{BD}$ & S; Depth & Carbon Stock \\
\hline 8 & $10-8-1$ & $\mathrm{pH} ; \mathrm{BD}$ & S; Depth & Carbon Stock \\
\hline 9 & $3-5-1$ & $\mathrm{pH} ; \mathrm{BD}$ & - & Carbon Stock \\
\hline
\end{tabular}

pH: Hydrogenionic Potential; ECEC: Effective Cation Exchange Capacity; P: Phosphorus; K: Potassium; Ca: Calcium; Mg: Magnesium; BD: Bulk Density; S: Soil classes.

The best result was chosen based on the network that obtained the highest Pearson correlation coefficient (r) between the observed and estimated values for the validation data set. Having close results in the architecture choice, we selected the one with the lowest mean square error over the training data, and the one with fewer neurons in the hidden and input layers, in order to reduce the possibility of overfitting (Braga et al., 2007).

The best ANN were selected based on the Pearson correlation coefficient (r), square root of the mean error (SRME) and graphical analysis of the residuals dipersion on the basis of observed and estimated values (Pearson, 1920 ; Mehtätalo et al, 2006).

$$
\mathrm{r}=\frac{\sum\left(\mathrm{x}_{\mathrm{i}}-\dot{x}\right)\left(\mathrm{y}_{\mathrm{i}}-\hat{\mathrm{y}}\right)}{\sqrt{\left(\sum\left(\mathrm{x}_{\mathrm{i}}-\hat{x}\right)^{2}\right)\left(\sum\left(\mathrm{y}_{\mathrm{i}}-\hat{y}\right)^{2}\right)}}
$$

Where: $\mathrm{y}_{\mathrm{i}}=$ carbon stock output values observed in chemical analysis; $\overline{\mathrm{y}}=$ average carbon stock output values observed in chemical analysis; $\mathrm{x}_{\mathrm{i}}=$ output values of carbon stock estimated by ANN; $\dot{x}=$ average of thecarbon stock output values estimatedby ANN.

$$
\operatorname{SRME}(\%)=100 \sqrt{\frac{\sum_{\mathrm{i}=1}^{\mathrm{n}}\left(\mathrm{Y}_{\mathrm{i}}-\hat{Y}_{\mathrm{i}}\right)^{2}}{\mathrm{n}}} / Y^{\prime}
$$

Where: $Y_{i}=$ carbon stock output observed in chemical analysis; $\hat{\mathrm{Y}}_{\mathrm{i}}=$ estimated carbon stock output; $\overline{\mathrm{Y}}=$ average of the carbon stock output observed; $n=$ total number of data.

\section{RESULTS AND DISCUSSION}

The best network for each set of predictor variables was chosen from the 36 tested architectures, based on the statistical characteristics of SRME (\%) and correlation (r) between observed and estimated values in the training and validation processes (Table 2). The best correlation values, both in training and in the validation, were observed for ANN 1 that comprises all physical and chemical parameters of the soil (0.97 to 0.93$)$ and for ANN 2 with chemical variables $(0,98$ and 0.93$)$, whereas for both cases soil classes and sampled depths were considered.

Table 2: Statistical features of selected ANN to estimate soil carbon stockin a fragment of semi-deciduous submontane forest, in the state of

\begin{tabular}{|c|c|c|c|c|c|c|}
\hline \multirow{2}{*}{ ANN } & \multicolumn{3}{|c|}{ Training } & \multicolumn{3}{|c|}{ Validation } \\
\hline & Bias & SRME $(\%)^{*}$ & $\mathrm{r}^{* *}$ & Bias & SRME (\%) & $\mathrm{r}$ \\
\hline 1 & 15,52 & 17,24 & 0,9696 & 13,20 & 14,35 & 0,9303 \\
\hline 2 & 15,38 & 17,12 & 0,9798 & 14,53 & 16,31 & 0,9301 \\
\hline 3 & 15,39 & 16,66 & 0,9230 & 15,02 & 16,47 & 0,8728 \\
\hline 4 & 15,37 & 16,99 & 0,9546 & 14,99 & 16,79 & 0,9251 \\
\hline 5 & 15,49 & 17,00 & 0,9139 & 14,42 & 15,82 & 0,8955 \\
\hline 6 & 14,82 & 15,59 & 0,6778 & 14,40 & 15,33 & 0,7073 \\
\hline 7 & 15,66 & 16,99 & 0,8720 & 14,32 & 15,78 & 0,9247 \\
\hline 8 & 15,32 & 16,68 & 0,9100 & 15,63 & 17,42 & 0,8998 \\
\hline 9 & 15,60 & 16,46 & 0,6568 & 14,96 & 15,57 & 0,6633 \\
\hline
\end{tabular}
Espírito Santo. 
The soil class has an influence on the carbon stock due to the type of aggregates that are formed, increasing or decreasing the mineralization of organic matter and, consequently, the soil carbon stock. As for depth,generally SOC concentrations are higher in the superficial layers, decreasing exponentially with increasing depth (Rosa et al., 2014).

In general, the availability of nutrients is influenced by soil $\mathrm{pH}$. This attribute, as well as potassium, is linked to the stock of organic carbon, inferring that the $\mathrm{pH}$ in the proper range favors the maintenance of basic cations in the soil.

In addition, the stock of SOC is correlated with chemical properties, as it causes the significant increase in the cation exchange capacity and in nutrient availability, especially in soils with predominantly low activity clay (Ciotta et al., 2003). However, as the SOC stock decreases with increasing depth, its effect on fertility is also reduced (Teixeira et al., 2003). The physical characteristics of the soil also have an influence on carbon stock, since the bulk density can be decreased by the increased amount of organic matter and lower clay content (Braida et al, 2006). Therefore, the relationship between carbon stock and soil physical properties is considered directly proportional, increasing the carbon stock as the density of the soil increases (Rangel\& Silva, 2007).

The highest correlation observed for ANN 1 and 2 can be explained by the influence of physical and chemical properties on the stock of soil carbon. Furthermore, the use of higher number of variables in estimating ANN enhances the values of the statistical parameters [r and SRME (\%)] (Soares et al., 2014).

However, as noted in Table 2, other networks (ANN 3, 4, 5, 7 and 8) showed correlationvalues greater than 0.87, which is considered to be strongly correlated (Zou et al., 2003), setting variables with lower complexity and cost to estimate the stock of soil carbon.

In the residual analysis (Figure 1), it was possible to confirm that ANN 1 and 2 present the best estimation results, confirming the statistical analysis already mentioned in this study. The graphical analysis allows you to view a homogeneous pattern in ANN 1 and 2, with dispersion of the residuals below 50\%, unlike what happens with the other ANN. Note that artificial neural networks have demonstrated a tendency to overestimate the smallest values of the amount of soil carbon stock.

The input variables for the neural network used in this study are relatively easy to obtain, providing the use of the proposed methodology for the estimation of the stock of soil organic carbon. Moreover, increased accuracy of the projections may be feasible by the inclusion of categorical input variables.

\section{Conclusions:}

The use of ANN to estimate the stock of soil organic carbon in a fragment of semi-deciduous submontane forest is efficient and reduces the number of physical and chemical analysis. Consequently, it is possible to reduce the cost of laboratory tests and the time dispended in fieldwork.

The higher the number of input variables better results of prediction will be, however, it is up to the professional to decide the degree of reliability ( $r$ ) that matches your need, and thus opt for a reliable ANN architecture to estimate the soil organic carbon through input variables of lowercost of data collection and analysis.

However, the first option of neural networks (ANN 1) that uses more physical and chemical variables is an alternative of higher cost to predict the stock of soil organic carbon. As the second option (ANN 2) has a better viability by only using chemical attributes for prediction of carbon stock, which reduces the time and cost for obtaining the sample from SOC stock.

The advantages of the ANN included the following: a) decreased subjectivity in the determination of soil carbon storage; b) the ability to consider a greater or smaller number of classification variables; c) elimination of the need for pre-existing analysis in the study area; d) the ability to use the tested network architecture application to predict soil units in homologous regions; e) assignment of random weights based on training samples, which reduces errors in the operation process.

As well as facilitating predicting soil carbon storage, this approach contributes to the development of an alternative to facilitate futures studies, especially considering the availability of the data at zero cost, ease of obtaining terrain attributes and use of free software. 

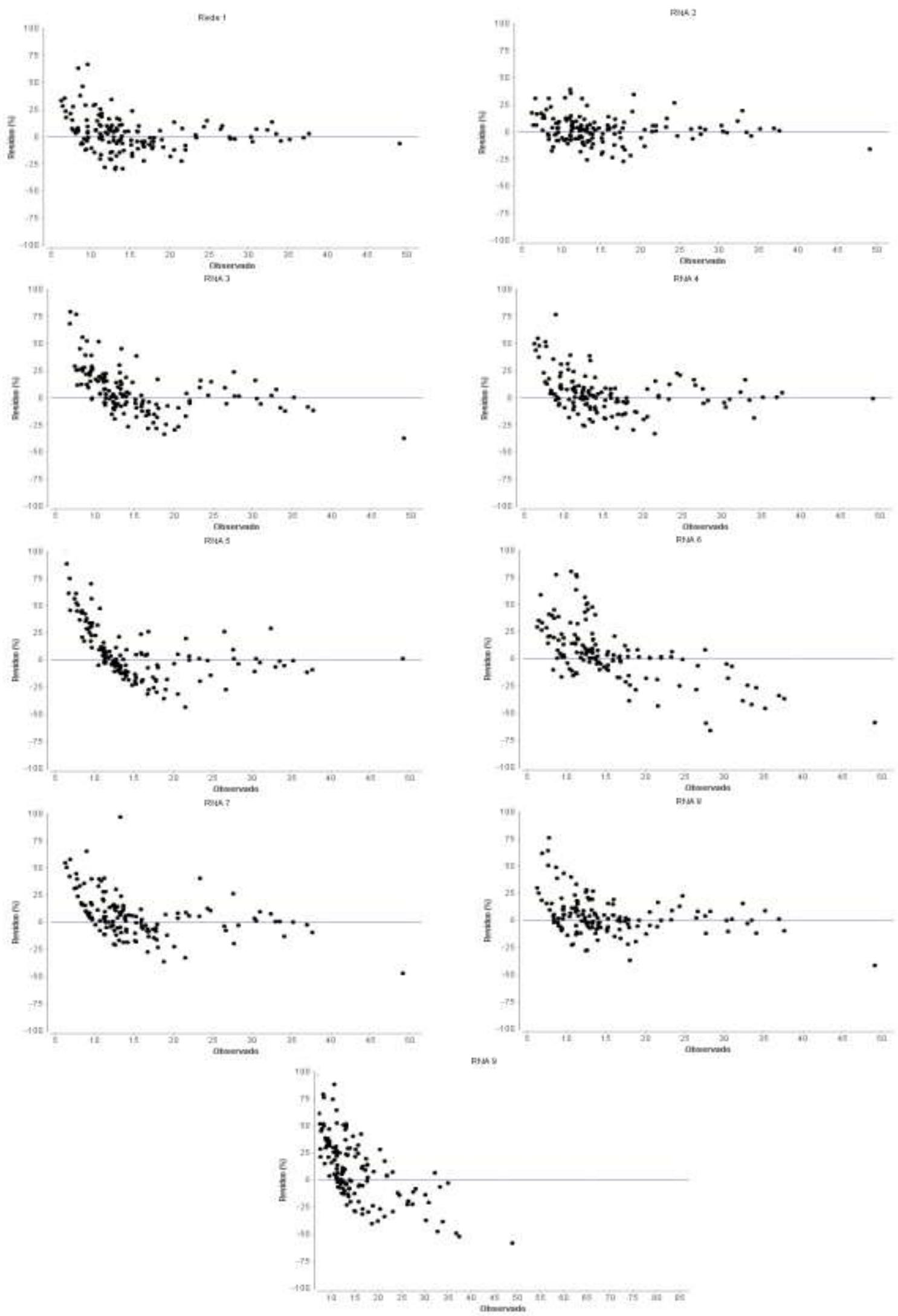

Fig. 1: Dispersion of residuals of carbon stock estimates by artificial neural networks (y) due to the observed values $(\mathrm{x})$ in a fragment of semi-deciduous submontane forest, in the state of Espírito Santo. 


\section{Future Work:}

The results of the use of neural network system for soil organic carbon stock prediction are favorable. However, further work should be carried out with different configurations of neural networks, i.e. using different architectures to obtain better correlation between the data of SOC stock and the physical and chemical soil properties, thus obtaining minor error in the response variable estimates.

\section{REFERENCES}

Alvares, C.A., J.L. Stape, P.C. Sentelhas, J.L.M. Gonçalves and G. Sparovek, 2013. Köppen's climate classification map for Brazil. Meteorologische Zeitschrift, 22: 711-728. http://dx.doi.org/10.1127/09412948/2013/0507.

Arruda, G.P., J.A. M.Demattê and C.S. Chagas, 2013. Mapeamento digital de solos por redes neurais artificiais com base na relação solo-paisagem. Revista Brasileira de Ciência do Solo, 37: $327-$ 338.http://dx.doi.org/10.1590/S0100-06832013000200004.

Binoti, D.H.B., M.L.M.S. Binoti, H.G. Leite and P.F. Lopes, 2014. NeuroForest (Software) versão $3.3-$ Sistema para Aplicação de Redes Neurais Artificiais. Viçosa, MG. Available in: http://neuroforest.ucoz.com. Acesso em: 20 jun 2015.

Braga, A.P., A.P.L.F.Carvalho and T.B., Ludermir, 2007. Redes neurais artificiais: Teoria e aplicações. 2ed. Rio de Janeiro: LTC.

Braida, J.A., J.M. Reichert, M. Veiga and, D.J. Reinert, 2006. Resíduos vegetais na superfície e carbono orgânico do solo e suas relações com a densidade máxima obtida no ensaio Proctor. Revista Brasileira de Ciência do Solo, 30:605-614.http://dx.doi.org/10.1590/S0100-06832006000400001.

Bucene, L.C. and L.H.A. Rodrigues, 2004. Utilização das Redes Neurais Artificiais para avaliação da produtividade do solo, visando classificação de terras para irrigação. Revista Brasileira de Engenharia Agrícola e Ambiental, 8: 326-329.

Carneiro, M.A.C., E.D. Souza, E.F. Reis, H.S. Pereira and W.R. Azevedo, 2009. Atributos físicos, químicos e biológicos de solo de cerrado sob diferentes sistemas de uso e manejo. Revista Brasileira de Ciência do Solo, 33: 147-157.http://dx.doi.org/ 10.1590/S0100-06832009000100016.

Chen, W.C., L.Y. Tseng and C.S.A. Wu, 2014, unified evolutionary training scheme for single and ensemble of feedforward neural network, Neurocomputing, 143: $347-361$. http://dx.doi.org/10.1016/j.neucom.2014.05.057.

Ciotta, M.N., C. Bayer, S M.V. Fontoura, P.R. Ernani and J.A. Albuquerque, 2003. Matéria orgânica e aumento da capacidade de troca de cátions em solo com argila de atividade baixa sob plantio direto. Ciência Rural, 33: 1161-1164.http://dx.doi.org/10.1590/S0103-84782003000600026.

Curto, R.A., G.F. Silva, R. Môra, R.O.V. Miranda, A.P.D Fernandes and E.J.G. Araújo, 2015. Structure of the arboreal component of a Semideciduous Seasonal Forest in the south of Espirito Santo state, Brazil. Australian Journal of Basic and Applied Sciences, 9(20): 176-186.

Empresa Brasileira de Pesquisa Agropecuária (EMBRAPA). 1997. Manual de métodos de análise de solo. 2ed. EMBRAPA-CNPS, Rio de Janeiro, Brasil.

Freixo, A.A., P.L.O.A. Machado, Guimarães, C.M. Guimarães, C.A. Sil va and F.S. Fadigas, 2002. Estoques de carbono e nitrogênio e distribuição de frações orgânicas de Latossolo do Cerrado sob diferentes sistemas de cultivo. Revista Brasileira de Ciência do Solo, 26: 425-434.http://dx.doi.org/10.1590/S010006832002000200016.

IBGE. Folha SE. 24 Rio Doce: geologia, geomorfologia, pedologia, vegetação, uso potencial da terra (1987). Série 34. Rio de Janeiro: IBGE.

Leal, A.J.F., E.P. Miguel, F.H.R. Baio, D.C. Neves and U.A.S. Leal, 2015. Redes neurais artificiais na predição da produtividade de milho e definição de sítios de manejo diferenciado por meio de atributos do solo.Bragantia, 74: 436-444. http://dx.doi.org/10.1590/1678-4499.0140.

Marouni, L.F., J.L.Magalhães, A.A.Rodrigues, D.A.Rodrigues, P.A.N.R.Magalhães, M.S.Di Campos,C.L.Rodrigues, R.G.Vital, T.F.Cavalcante, F.B.Silva, E.M.G.Teles, R.G.Guimarães Junior, 2016. Growth of eucalyptus seedlings irrigated with different vinasse concentrations. Australian Journal of Basic and Applied Sciences., 10(18): 115-121.

Mehtätalo, L., M. Maltamo and A. Kangas2 006. The use of quantile trees in the prediction of the diameter distribution of a stand. Silva Fennica, 40: 501-516. http://dx.doi.org/10.14214/sf.333.

Pearson, K., 1920. Notes on the history of correlation. Biometrika, 13: 25-45. http://dx.doi.org/10.1093/biomet/13.1.25.

Rangel, O.J. Pand C.A. Silva, 2007. Estoques de carbono e nitrogênio e frações orgânicas de Latossolo submetido a diferentes sistemas de uso e manejo. Revista Brasileira de Ciência do Solo., 31: 1609-1623. http://dx.doi.org/10.1590/S0100-06832007000600037. 
Ribeiro, D. O., M. R. Carballal; A. J. da Silva; A. J. F. Leal; J. O. Caetano; A. A. Rodrigues; R. G. Vital; R. L. F. Prado; H. D. da Silva; M. B. M. Filho., Organic Fertilization In Soy Farming In A Tropical Region. Aust. J. Basic \& Appl. Sci., 11(7): 18-22, 2017

Rosa, R., E.E. Sano and J.S. Rosendo, 2014. Estoque de carbono em solos sob pastagens cultivadas na bacia hidrográfica do Rio Paranaíba. Sociedade \& Natureza, 26: 333-351. http://dx.doi.org/10.1590/1982451320140210.

Santos, H.G., P.K.T. Jacomine, L.H.C. Anjos, V.A. Oliveira, J.F. Lumbreras, M.R. Coelho, J.A. Almeida, T.J.F. Cunha and J.B. Oliveira, 2013. Sistema brasileiro de classificação de solos. 3ed. Brasília: Embrapa.

Silva, R.G., M.C. Alves., R.A.V.B. Faria, L.M.T. Carvalho, S.A. Botelho., Ecological Restoration Indicators apllied to Permanent Preservation Areas surrounding the springs. Aust. J. Basic \& Appl. Sci., 10(9):132-139, 2016

Silva, I.N., H.D. Spatti and R.A. Flauzino, 2010. Redes Neurais Artificiais para engenharia e ciências aplicadas. São Paulo: Artliber.

Silveira, C.T., C. Oka-Fiori, L.J.C. Santos, A.E. Sirtoli, C.R. Silva and M.F. Botelho, 2013. Soil prediction using artificial neural networks and topographic atributes. Geoderma, 1: 195-196.

Soares, F.C., A.D. Robaina, M.X. Peiter, J.L. Russi and G.A. Vivam, 2014. Redes neurais artificiais na estimativa da retenção de água do solo. Ciência Rural, 44: 293-300.http://dx.doi.org/ 10.1590/S010384782014000200016.

Sousa Junior, J.G., J.A.M. Demattê and S.R. Araújo, 2011. Modelos espectrais terrestres e orbitais na determinação de teores de atributos dos solos: potencial e custos. Bragantia, 70: 610-621. http://dx.doi.org/10.1590/S0006-87052011000300017.

Teixeira, I.R., C.M. Souza, A. Borém and G.F. Silva, 2003. Variação dos valores de pH e dos teores de carbono orgânico, cobre, manganês, zinco e ferro em profundidade em Argissolo Vermelho-Amarelo, sob diferentes sistemas de preparo de solo. Bragantia, 62: 119-126. http://dx.doi.org/10.1590/S000687052003000100015 .

Ziembowicz, M.M., J. M., J. Baratto., E. Alba., J. A. S. Favarin, M. S. Schuh, T. L. Badin, R. S. Pereira. Analysis of the fragmentation of the Atlantic Forest in an area under influence of a hydroelectric plant in Rio Grande do Sul, Brazil. Aust. J. Basic \& Appl. Sci., 11(12): 41-50, 2017

Zou, K.H., K. Tuncali and S.G. Silverman, 2003. Correlation and simple linear regression. Radiology, 227: 617-622.http://dx.doi.org/10.1148/radiol.2273011499. 